\title{
THE TYRANNY OF MERIT: WHAT'S BECOME OF THE COMMON GOOD
}

\author{
Michael Sandel (Author) \\ Penguin Books, 2020, 288 p. ISBN: 9780241407608
}

Roxana-Elisaebeta MARINESC $\mathbf{U}^{1}$

In a Ted Talk (https://www.ted.com/talks/michael_sandel_the_tyranny_of merit/transcript) in which he promoted his latest book, The Tyranny of Merit (Penguin Books, 2020), Harvard Professor of political philosophy Michael Sandel mentioned the divide between winners and losers which had been setting the American society apart. It is a clear inequality of opportunity which lies at the very basis of this divide, and, moreover, an attitude in the society, enhanced by politicians, educators, the media, etc., which emphasizes the merit of the ones landing on top and the blame on the ones who did not succeed. Thus, the myth of meritocracy undermines the very fibre of American (and not only) democracy:

"Meritocracy is corrosive of the common good. It leads to hubris among the winners and humiliation among those who lose out. It encourages the successful to inhale too deeply of their success, to forget the luck and good fortune that helped them on their way. And it leads them to look down on those less fortunate, less credentialed than themselves."

It all started, argues Sandel, with the Democratic party leaders in the US and their equivalent in Western Europe championing an "age of merit" as the solution to the challenges of globalization, inequality and deindustrialization. This has led to rifts in society to which complex democratic challenges, such as the election of Trump in 2016 (and Brexit in Europe), is only the most visible effect. The meritocratic myth seems not to take into consideration the level at which we start in life (an intersection between family status, class, gender, ethnicity, the environment, etc.) and how it contributes to our development. It is based on the individualism prevalent in some societies (American, British) and to which others strive to reach (y compris Romania, it seems in an accelerated rush towards illiberal populism). For how could we make equal opportunities really work? To what extent is the individual responsible for their own success and what is the role of society in enabling its individuals for their own

\footnotetext{
${ }^{1}$ Roxana-Elisabeta-Marinescu, Bucharest University of Economic Studies, roxana.marinescu@rei.ase.ro
} 
success? In other words, is it enough for the society to proclaim equal opportunities (for example, in education, by stating in the law and the Constitution that it is equal and free, that it is the right of all its citizens)? And therefore, meritorious individuals will succeed, and the ones lacking merit will fail? How is this success/ failure measured? If one succeeds, it is their own individual merit; if one fails, it is their blame, as the society offered them the instruments, but they did not access them. All pertinent questions to which Sandel gives a personal answer in this book.

So, according to Sandel, there is a tyranny of meritocracy and credentials: in the meritocratic paradigm, the successful (read 'meritocratic') people have a sort of arrogance of their success, as they (and the others) believe they managed success through their own merit, and they do not need to empathize or even relate to the ones who did not succeed. The latter, even though had the same opportunities, did not make the best of them, so do not deserve any sympathy. According to Sandel this has brought about anti-establishment movements and populism, as the 'unmeritocratic' and 'un-credentialed' felt pushed away and relegated to the margins of society. However, at present, the covid-19 pandemic offered a new framework in which the common good should prevail; in this new framework, essential workers, i.e. the ones without whom we could not have continued our lives (garbage collectors, nurses, supermarket workers, etc.), are not the ones who previously would have been considered successful. It is therefore time to reconsider the very idea of success based on meritocracy and credentialism.

The American dream is about social mobility, and in theory the US is the land of all possibilities in which the rags-to-riches script is part of the canon. Sandel notices that statistically old Europe allows a better social mobility, in spite of the initial ideal of the first pilgrims who set foot in the new world and the successive waves of immigrants, in search of that socially mobile society. In order to show this, Sandel analyzes representativity in the US Congress and the British Parliament and he notes that in the last decades there are fewer and fewer un-credentialed representatives; moreover, more and more of them are highly credentialed, the majority Ivy League (or Oxbridge) graduates. In context, let us remember the campaign(s) on politicians' credentials in Romania (positive and negative) and their determination to acquire as many credentials as possible (sometimes simultaneously). The discussion could include what we consider merit here and what model we try to copy when we value meritocracy and credentialism above everything else (in theory only, as when the Romanian society seems very relaxed when judging based on political bias).

Similarly, the speeches of American presidents (Clinton, Bush, and especially Obama) underline university education as the basis of success and give themselves or members of their family as examples. Tokenism is clearly at play: Michelle Obama started from a South-Chicago poor neighborhood and succeeded to study at Harvard, through her own merit. Therefore, success for the poor is possible; who did not succeed, it's on them. 
The solution? Michael Sandel proposes the "equality of condition" as a valid alternative to the "equality of opportunity", and not the "equality of results", for him "a sterile, oppressive" alternative, although considered by many as the only one possible. (p. 224) This could offer the possibility to those not as lucky to move up the social ladder, the possibility to exercise their abilities with decency and dignity and to live an equally fulfilling life. The civic conception of the common good (as opposed to the consumerist one) would make us admit with humility that we are not self-made and self-sufficient and that the merit that we believe to have been at the basis of our success is largely accidental. Solidarity should be the underlying project of our society, a project which would save our democratic societies from the perils of populism and illiberalism.

The book is reader friendly, the theoretical framework is clearly described, and a score of examples from recent history make it all the more pertinent (such as US university admissions in 2019, in which 33 wealthy parents, among whom Hollywood actors, were charged with accessing an elaborate scheme to be admitted to elite universities, such as Yale, Stanford, Georgetown and the University of Southern California). For Romanian readers, it is cross-culturally relatable as the same issues seem to be highly debated in the Romanian society nowadays; the mantras of meritocracy and credentialism have been brought about and tossed over in the public discussion whenever convenient for political pressure groups and depending on their immediate gains. Therefore, I am highly confident that this book will me meaningful to Romanian readers, able to critically understand the American system, mutatis mutandis. 